\title{
Gender Differences in Environmentalism: A Case Study of Macedonian Students
}

Summary: This study focuses on the impact of gender on environmental worldview in a sample of Macedonian students. The sample used in the final analysis consisted of 448 Macedonian students from 7 elementary and high schools. Participants completed the New Ecological Paradigm scale (NEP; Dunlap et al., 2000). Empirical findings suggest that no firm and clear conclusions can be drawn about the effects of gender on (NEP) environmental concern in a sample of Macedonian students. Findings are discussed in terms of differences between two groups.

Key words: environmentalism, NEP scale, students, gender, Macedonia.

\section{Introduction}

"Humanity has the ability to make development sustainable to ensure that it meets the needs of the present without compromising the ability of future generations to meet their own needs (World Commission on Environment and Development" (1987: 16). This requires profound changes in thinking, in economic and social structures and in consumption and production patterns (European Commission, 2016). Human behavior change is also necessary for mitigation and adaptation. This means that the psychological and sociological study of sustainable behavior and environmentalism are important. Environmentalism is defined as "a different

1 m.srbinovski@seeu.edu.mk Copyright $\odot 2016$ by the authors, licensee Teacher Education Faculty University of Belgrade, SERBIA.

This is an open access article distributed under the terms of the Creative Commons Attribution License (CC BY 4.0) (https://creativecommons.org/licenses/by/4.0/), which permits unrestricted use, distribution, and reproduction in any medium, provided the original paper is accurately cited. way of thinking in which people try to care more about the planet and the long-term survival of life on Earth" (Chris Woodford, 2016: 1).

One of the ways psychologists can promote environmentalism is to understand the relationship between personal factors and environmental attitudes and behaviors. "Although at first glance, the relationship between human society and the physical environment seems to be gender neutral, affecting both women and men in a similar way, upon closer examination one realizes that the relationship is not neutral. The differentiated socio-cultural construction of men and women's roles means that the linkages between people and the physical environment impact differently on both sexes. As men and women have different roles in 
the family, community and work-force, they are likely to have different personal attitudes, priorities and power over resources when it comes to environmental protection. Men and women also interact differently with the environment, which provides them with different opportunities to protect it" (OSCE, 2009: 17).

This study focuses on the impact of gender on environmental worldview and concern. Environmental worldview can be defined as "the collective beliefs and values that give people a sense of how the world works, their role in the environment, and right and wrong behavior toward the environment. Environmental worldviews dictate how we interact with nature and our attitude toward how we use the natural resources it contains" (Gillaspy, 2015: 1). Environmental concern is defined as "the affect (i.e., worry) associated with beliefs about environmental problems" (Schultz et al., 2004: 31). "Social scientists are motivated to study environmental concern because if we are to move towards environmental sustainability, we need to better understand the environmental worldviews that influence resource consumption and pollution" (Castro, 2006: 248), as a relevant part of the "circumstances under which individuals and groups make decisions and enact behaviors that affect levels of resource consumption and environmental pollution" (Stokols, 1995: 828).

There are many scale to measure environmental attitudes and concern (see: Maloney, Ward, and Braucht, 1975; Weigel and Weigel, 1978; Wiseman and Bogner, 2003; Dunlap and Van Liere, 1978). A widely used measure of environmental worldview is Dunlap and Van Liere's New Environmental Paradigm (NEP) scale, first published in 1978. The scale was revised by Dunlap et al. (2000) and became the New Ecological Paradigm Scale (Dunlap et al., 2000: 433). The revised NEP Scale appears to be an improved measuring instrument compared to the original version, as it (1) provides more comprehensive coverage of the key facets of an ecological worldview: the reality of limits to growth, antianthropo- centrism, the fragility of nature's balance, rejection of exemptionalism, and the possibility of an ecocrisis, (2) avoids the unfortunate lack of balance in the item direction of the original scale (where only four items, all dealing with anthropocentrism, were stated in an anti-NEP direction, and (3) removes the outmoded, sexist terminology in some of the original scale's items (Dunlap et al. 2000: 425).

Relatively little information yet exists regarding gender differences in environmental worldview and environmentalism. In that direction, Mohai, P. (1992) point out: "although numerous studies have examined the relationship between demographic variables and environmental attitudes and behaviors, researches on environmentalism and gender have been somewhat limited" (Mohai, 1992: 2).

Although a few studies do not find differences (Stern et al., 1993; Arcury \& Christianson, 1993; Widegren, 1988), most find that women score higher than men on environmental concern (Zelezny et al., 2000; Tuncer et al., 2005: Schahn \& Holzer, 1990). For example, Zelezny et al. (2000: 443), found college women had higher NEP scores than college men in 10 of the 14 countries they surveyed (men had higher scores in three countries and there were no gender differences in one country- the United States). They also found women reported stronger environmental concern (more specifically, concern for nature, the biosphere, and all living things) in 12 of the 14 countries they studied. A cross-national analysis provides support for gender distinctions with regard to some environmental behaviors within most of the incorporated 22 national contexts (Hunter et al. 2004). However, Chinese women expressed lower levels of concern than men-a finding opposite of most Western studies (Xiao \& Hong, 2010). Likewise, Stern and Dietz (1994) reported that women had stronger biospheric and social-altruistic environmental values (cited by Burn et al., 2012). Schultz (2001) found women to score higher on all three value bases of environmental concern: egoistic, altruistic, and biospheric (cited by Burn et al., 2012). 
Environmental worldview in the Republic of Macedonia have been studied by many authors: Srbinovski 2001, 2004, 2005a, 2005b, 2006; Ismaili et al., 2009; Idrizi et al., 2014 etc. In the last twenty years approximately $74 \%$ of Macedonian students have been demonstrated mainly pro-environmental attitudes. With this study, we hope to give a modest contribution to the clarification of gender differences in environmental worldview in a sample of Macedonian students.

\section{Methods}

Base on the above rationale, the following hypothesis was put forward: Because most studies comparing women and men on the NEP found that women scored higher than men, we expected the same. We used revised New Environmental Paradigm scale or New Ecological Paradigm scale also known as the NEP scale developed by Dunlap et al. (2000). In contrast to the "dominant social paradigm" (DSP), which views humans as separate from, and superior to nature, the NEP conceives of environmental concern as endorsement of a new ecological worldview where humans are a part of nature (Burn et al.: 137). The 15-item revised NEP scale (Dunlap et al., 2000: 433) uses a 5-point Likert scale to measure endorsement of an ecological worldview (Table 1). Each item was measured on a scale ranging from 1 to 5 : strongly agree (5), agree (4), neither agree or disagree (3), disagree (2), and strongly disagree (1). The NEP score is calculated as the sum of positive responses for each item: strongly agree plus agree. As the directionality of the anthropocentric items was reversed, the NEP score of these items was adjusted. Mean total pro-NEP\% is average NEP score.

Agreement with the eight odd-numbered items indicates pro-NEP orientation, while agreement with the seven even numbered ones indicates pro-DSP orientation. The boundary between a proecological perspective and a human-dominance one is generally held to be a NEP score of 45 (Rideout, et al. 2005, cit. in Van Petegem and A. Blieck, 2006). People scoring below 45 tend to be more in favour of the DSP worldview, whereas those with scores higher than 45 tend to be more in favour of the NEP worldview (Van Petegem and A. Blieck, 2006).

Table 1. Items in revised NEP Scale

(Dunlap et al., 2000).

1. We are approaching the limit of the number of people the earth can support

2. Humans have the right to modify the natural environmental to suit their needs

3. When humans disturb interfere with nature it often produces disastrous consequences.

4. Human ingenuity will insure that we do NOT make the earth unlivable.

5. Humans are severely abusing the environment.

6. The earth has plenty of natural resources if we just learn how to develop them.

7. Plants and animals have as much right as humans to exist.

8. The balance of nature is strong enough to cope with the impacts of modern industrial nations.

9. Despite our special abilities humans are still subject to the laws of nature.

10. The so-called "ecological crisis" facing humankind has been greatly exaggerated.

11. The earth is like a spaceship with very limited room and resources.

12. Humans were meant to role over the rest of nature.

13. The balance of nature is very delicate and easily upset.

14. Humans will eventually learn enough about how nature works to be able to control it.

15. If things continue on their present course, we will soon experience a major ecological catastrophe.

The NEP scale was tested for reliability using Cronbach's $\alpha$. For the pilot study, Cronbach's $\alpha$ for this scale was within acceptable internal consistency (.71).

The sample used in the final analysis consisted of 448 Macedonian elementary and high school 
students (193 or $43.1 \%$ boys, and 252 or $56.3 \%$ females). The schools (7) were chosen for reasons of attainability and willingness to cooperate.

The principal components factor analysis (PCA) with varimax rotation was carried out in order to find out the existence of dimensions. The main goal of this transformation technique is to detect the correlation between variables. If a strong correlation between variables exists, the attempt to reduce the dimensionality only makes sense (Rasch$\mathrm{ka}, 2015)$. Varimax rotation is used to simplify the expression of a particular sub-space and to create orthogonal dimensions. In order to test the equality of two population (or treatment) means by examining the variances of samples that are taken, we used a hypothesis-testing technique or analysis of variance (ANOVA). ANOVA allows one to determine whether the differences between the samples are simply due to random error (sampling errors) or whether there are systematic treatment effects that cause the mean in one group to differ from the mean in another (UALR College of Business, 2016). In this study we analyzed the differences between the samples.

\section{Results}

Mean total pro-NEP\% of females and boys are almost identical (56.63\% and 56.80\%, respectively). The chi-square tests provided no support on 11 items for the hypothesis (Table 2). Chi square test results showed that females and boys significantly differ in 4 out of 15 items. There were significant differences of opinion on two statements at .05 level (items 4 and 15) and two at .01 level (items 11 and 13).

Range on the agreement responses of females and boys on the pro-environmental items are 50.0 to $96.05 \%$ and 58.03 to $92.71 \%$, respectively. Mean total on these items of females and boys are in favor of the NEP worldview ( $80.91 \%$ and $80.40 \%$, respectively).

There is no difference in worldviews of boys and females on pro-NEP statements $\left(\chi^{2}=0.267\right)$. The range of differences in responses between females and boys are from 1.5\% to18.23\%. Maximum differences are regarding the $\left(11^{\text {th }}\right.$ and $13^{\text {th }}$ statements "The earth is like a spaceship with very limited room and resources" (boys $=68.23 \%$, female $=50 \%$ ), and "The balance of nature is very delicate and easily upset" boys $=86.01 \%$, female $=95.68 \%$ ).

Although mean total pro-DSP\% of females and boys are also almost identical $(48.02 \%$ and $47.96 \%$, respectively), there is marked difference in worldviews of boys and females on these statements $(\chi 2=21.71, p=.01)$. The range of differences in responses between females and boys are from $0.26 \%$ $-7.03 \%$. Maximum differences are regarding the $\left(8^{\text {th }}\right.$ and $4^{\text {th }}$ ) statements: "The balance of nature is strong enough to cope with the impacts of modern industrial nations" (boys $=49.74 \%$, female $=56.87 \%$ ), and "Human ingenuity will insure that we do NOT make the earth unlivable" (boys $=32.64 \%$, female $=27.45 \%$ ). Perhaps this difference is due to fact that the boys students have more positive attitude towards science than female students (Banu, 1986). From that, they might have higher level of knowledge about science and human abilities.

We agree with Rideout et al., (2005), and Van Petegem and A. Blieck (2006) that NEP item 6 ("The earth has plenty of natural resources if we just learn how to develop them") was probably misinterpreted by the respondents. Perhaps this is due to its content. This item includes two different elements: knowledge of natural resources, and knowledge about learning process and education. It appears ambiguous or not clearly understandable for Macedonian children.

In order to simplify the expression of a particular sub-space in terms of just a few major items each, we used a principal components factor analysis (PCA) with varimax rotation, showing four dimensions named "Balance of Nature", "Humans over Nature", "Anti anthropocentrism" and "Limit to growth". Items 5, 3, 15, 9 and 8 loaded heavily on the "Balance of Nature' component, four items (14, 2, 10 and 6) 
Table 2. Frequency distributions for the NEP scale by gender

\begin{tabular}{|c|c|c|c|c|c|c|c|c|c|}
\hline Item & Gender & SD & $\mathrm{D}$ & $\begin{array}{c}\text { Neither A } \\
\text { or D }\end{array}$ & A & SA & $\begin{array}{c}\text { Missing } \\
\text { cases }\end{array}$ & $\begin{array}{l}\text { NEP } \\
\text { score }\end{array}$ & $\chi^{2}$ \\
\hline \multirow[t]{2}{*}{1} & boys & $1.55(3)$ & $15.54(30)$ & $24.87(48)$ & $39.38(76)$ & $18.65(36)$ & $0(0)$ & 58.03 & \multirow[t]{2}{*}{1.88} \\
\hline & female & $.4(1)$ & $16.6(42)$ & $26.48(67)$ & $38.74(98)$ & $17.79(45)$ & $.78(2)$ & 56.53 & \\
\hline \multirow[t]{2}{*}{2} & boys & $5.7(11)$ & $8.81(17)$ & $11.4(22)$ & $22.28(43)$ & $51.81(100)$ & $0(0)$ & 14.51 & \multirow[t]{2}{*}{2.79} \\
\hline & female & $2.76(7)$ & $8.27(21)$ & $11.42(29)$ & $25.20(64)$ & $52.36(133)$ & $.4(1)$ & 11.03 & \\
\hline \multirow[t]{2}{*}{3} & boys & $1.04(2)$ & $3.13(6)$ & $3.13(6)$ & $26.56(51)$ & $66.15(127)$ & $.52(1)$ & 92.71 & \multirow[t]{2}{*}{2.23} \\
\hline & female & $.78(2)$ & $1.57(4)$ & $3.92(10)$ & $30.59(78)$ & $63.14(161)$ & $0(0)$ & 93.73 & \\
\hline \multirow[t]{2}{*}{4} & boys & $6.22(12)$ & $26.42(51)$ & $37.31(72)$ & $25.91(50)$ & $4.15(8)$ & $0(0)$ & 32.64 & \multirow[t]{2}{*}{$10.28^{\star}$} \\
\hline & female & $3.53(9)$ & $23.92(61)$ & $38.82(99)$ & $21.96(56)$ & $11.76(30)$ & $0(0)$ & 27.45 & \\
\hline \multirow[t]{2}{*}{5} & boys & $2.08(4)$ & $5.21(10)$ & $11.46(22)$ & $43.75(84)$ & $37.50(72)$ & $.52(1)$ & 81.25 & \multirow[t]{2}{*}{8.81} \\
\hline & female & $.39(1)$ & $3.53(9)$ & $8.63(22)$ & $38.04(97)$ & $49.41(126)$ & $0(0)$ & 87.45 & \\
\hline \multirow[t]{2}{*}{6} & boys & $0(0)$ & $.52(1)$ & $3.63(7)$ & $33.68(65)$ & $62.18(120)$ & $0(0)$ & .52 & \multirow[t]{2}{*}{6.64} \\
\hline & female & $0(0)$ & $.78(2)$ & $4.31(11)$ & $22.75(58)$ & $72.16(184)$ & $0(0)$ & .78 & \\
\hline \multirow[t]{2}{*}{7} & boys & $1.55(3)$ & $4.15(8)$ & $5.70(11)$ & $29.53(57)$ & $59.07(114)$ & $0(0)$ & 88.6 & \multirow[t]{2}{*}{5.84} \\
\hline & female & $.39(1)$ & $1.96(5)$ & $3.92(10)$ & $26.27(67)$ & $67.45(172)$ & $0(0)$ & 93.72 & \\
\hline \multirow[t]{2}{*}{8} & boys & $10.36(20)$ & $39.38(76)$ & $27.46(53)$ & $19.17(37)$ & $3.63(7)$ & $0(0)$ & 49.74 & \multirow[t]{2}{*}{4,36} \\
\hline & female & $8.63(22)$ & $48.24(123)$ & $22.75(58)$ & $15.69(40)$ & $4.71(12)$ & $0(0)$ & 56.87 & \\
\hline \multirow[t]{2}{*}{9} & boys & $.52(1)$ & $4.15(8)$ & $15.03(29)$ & $46.11(89)$ & $34.2(66)$ & $0(0)$ & 80.31 & \multirow[t]{2}{*}{7.38} \\
\hline & female & $1.57(4)$ & $5.88(15)$ & $18.43(47)$ & $50.59(129)$ & $23.53(60)$ & $0(0)$ & 74.12 & \\
\hline \multirow[t]{2}{*}{10} & boys & $9.84(19)$ & $31.09(60)$ & $27.98(54)$ & $24.35(47)$ & $6.74(13)$ & $0(0)$ & 40.93 & \multirow[t]{2}{*}{6.69} \\
\hline & female & $4.71(12)$ & $35.29(90)$ & $30.20(77)$ & $20.39(52)$ & $9.41(24)$ & $0(0)$ & 40.00 & \\
\hline \multirow[t]{2}{*}{11} & boys & $1.04(2)$ & $13.54(26)$ & $17.19(33)$ & $33.33(64)$ & $34.90(67)$ & $.52(1)$ & 68.23 & \multirow[t]{2}{*}{$32.43^{* *}$} \\
\hline & female & $6.69(17)$ & $20.47(52)$ & $22.83(58)$ & $35.43(90)$ & $14.57(37)$ & $.4(1)$ & 50.00 & \\
\hline \multirow[t]{2}{*}{12} & boys & $15.54(30)$ & $31.09(60)$ & $24.35(47)$ & $20.21(39)$ & $8.81(17)$ & $0(0)$ & 46.63 & \multirow[t]{2}{*}{5.57} \\
\hline & female & $8.63(22)$ & $35.69(91)$ & $27.06(69)$ & $20.39(52)$ & $8.24(21)$ & $0(0)$ & 44.32 & \\
\hline \multirow[t]{2}{*}{13} & boys & $2.59(5)$ & $3.63(7)$ & $7.77(15)$ & $30.57(59)$ & $55.44(107)$ & $0(0)$ & 86.01 & \multirow[t]{2}{*}{$13.73^{\star *}$} \\
\hline & female & $.39(1)$ & $1.18(3)$ & $2.75(7)$ & $34.9(89)$ & $60.78(155)$ & $0(0)$ & 95.68 & \\
\hline \multirow[t]{2}{*}{14} & boys & $7.25(14)$ & $16.58(32)$ & $23.32(45)$ & $33.68(65)$ & $19.17(37)$ & $0(0)$ & 23.83 & \multirow[t]{2}{*}{9.11} \\
\hline & female & $2.36(6)$ & $19.29(49)$ & $30.71(78)$ & $29.92(76)$ & $17.72(45)$ & $.4(1)$ & 21.65 & \\
\hline 15 & boys & $1.04(2)$ & $4.66(9)$ & $6.22(12)$ & $20.21(39)$ & $67.88(131)$ & $0(0)$ & 88.09 & $13,05^{\star}$ \\
\hline & female & $1.19(3)$ & $0.79(2)$ & $1.98(5)$ & $19.37(49)$ & $76.68(194)$ & $.78(2)$ & 96.05 & \\
\hline Mean total & boys & & & & & & & 56.80 & \\
\hline & female & & & & & & & 56.63 & \\
\hline
\end{tabular}

$\mathrm{N}=448$; frequency displayed in percentages, counts noted in brackets, $\chi^{2}$ - chi square test. $\mathrm{SD}$ - strongly disagree, $\mathrm{D}$ - disagree, $\mathrm{A}$ - agree, $\mathrm{SA}$ - strongly agree

$$
{ }^{\star} p=.05 .{ }^{* *} p=.01 \text {. }
$$

loaded on the 'Humans over Nature' component, two items (13 and 1) on the 'Limits to Growth' component and items 7, 4, 12 and 11 loaded on the "Anti anthropocentrism" component. Each of the four factors contains at least two out of five NEP dimensions which include issues of fragility of nature's balance, possibility of eco-crisis, anti-anthropocentrism, anti-exemptionalism and limits to growth. The first one of these four factors ("Balance of Nature") contains three related dimensions focusing on the issues of fra- 
gility of nature's balance, possibility of eco-crisis and anti-exemptionalism. These three dimensions include two items on the possibility of eco-crisis (item 5 and 15), two items on the fragility of nature's balance (items 3 and 8), and one item on anti-exemptionalism (item 9). The second factor ("Humans over Nature") has 4 items and includes one item on the possibility of eco-crisis (item 10), one on anti-exemptionalism (items 14), one on limits to growth (item 6) and one on anti-anthropocentrism (item 2). The third factor ("Anti-anthropocentrism") includes two items on anti-anthropocentrism (items 7 and 12), one on limits to Growth (item 11) and one on anti-exeptionalism (item 4). The fourth factor ("Limit to growth") consists of one item on limit to growth (item 1) and one on the fragility of nature's balance (item 13). Dunlap et al. (2000) cautioned that the dimensionality may depend on the specifics of the sample. The primary factors explained a total of $41 \%$ of the variance in results obtained (Table 3 and 4).

Table 3. Factor loadings in the $P C A^{*}$ of the revised NEP items with varimax rotation.

\begin{tabular}{ccccc}
\hline & \multicolumn{4}{c}{ Dimensions } \\
& 1 & 2 & 3 & 4 \\
\hline NEP 5 & .692 & .083 & .266 & -.043 \\
NEP 3 & .685 & .249 & .030 & .023 \\
NEP 15 & .631 & .098 & .177 & .184 \\
NEP 9 & .469 & .393 & -.222 & -.013 \\
NEP 8 & -.426 & .425 & -.264 & .131 \\
NEP 14 & -.149 & .617 & -.078 & -.049 \\
NEP 2 & -.270 & .527 & .232 & -.055 \\
NEP 10 & -.346 & .445 & .196 & -.181 \\
NEP 6 & .350 & .372 & -.148 & -.230 \\
NEP 7 & .461 & .209 & -.512 & -.072 \\
NEP 4 & -.232 & .417 & -.483 & -.020 \\
NE 12 & -.419 & .385 & .445 & .173 \\
NEP 11 & .222 & .341 & .399 & .213 \\
NEP 13 & .110 & .120 & -.080 & .822 \\
NEP 1 & .226 & .167 & .342 & -.359 \\
\hline${ }^{*}$ PCA- principal component analysis &
\end{tabular}

Table 4. Total variance explained, rotated components.

\begin{tabular}{|c|c|c|c|}
\hline \multirow{2}{*}{ Component } & \multicolumn{3}{|c|}{ Rotation Sums of Squared Loadings } \\
\cline { 2 - 4 } & Total & \% of Variance & Cumulative \% \\
\hline 1 & 1.689 & 11.263 & 11.263 \\
\hline 2 & 1.673 & 11.157 & 22.420 \\
\hline 3 & 1.441 & 9.604 & 32.024 \\
\hline 4 & 1.296 & 8.643 & 40.668 \\
\hline
\end{tabular}

In order to describe the results, we use descriptive table (Table 5). The descriptive table provides some very useful descriptive statistics, including the mean, standard deviation and $95 \%$ confidence intervals for the dependent variable for each separate factor, as well as when both groups are combined (Total).

The output of the ANOVA analysis and whether we have a statistically significant difference between our group means are shown on the Table 6 .

The test statistic for FA4 is the F value of 4.121. Since the test statistic is larger than the critical value, we reject the null hypothesis of equal population means and conclude that there is a (statistically) significant difference among the population means (Mean female $=3.84, \mathrm{SD}=0.61$; Mean boys $=3.71$, $\mathrm{SD}=0.70)$ in terms of FA4, $\mathrm{F}(1.44)=4.12, \mathrm{p}<.043)$.

\section{Discussion and conclusion}

Although more studies using the new ecological paradigm (NEP) typically find that women more strongly endorse the new ecological paradigm (Tikka et al., 2000; Blocker \& Eckberg, 1997; Scannell \& Gifford, 2013; Luchs \& Mooradian, 2012; Gutteling \& Wiegman, 1993), we found almost identical results for both groups, probably due to cultural similarity in traditional socialization. Smaller gender differences we might expect where traditional gender roles are more equal. A large majority of both female and boys students agree on all pro-environment statements. 
Table 5. Descriptive table

\begin{tabular}{|c|c|c|c|c|c|c|c|c|c|}
\hline & \multirow[b]{2}{*}{$\mathrm{N}$} & \multirow[b]{2}{*}{ Mean } & \multirow[b]{2}{*}{$\begin{array}{l}\text { Std. De- } \\
\text { viation }\end{array}$} & \multirow[b]{2}{*}{$\begin{array}{l}\text { Std. Er- } \\
\text { ror }\end{array}$} & \multicolumn{2}{|c|}{$\begin{array}{l}\text { 95\% Confidence } \\
\text { Interval for Mean }\end{array}$} & \multirow[b]{2}{*}{ Minimum } & \multirow[b]{2}{*}{$\begin{array}{l}\text { Maxi- } \\
\text { mum }\end{array}$} \\
\hline & & & & & & $\begin{array}{l}\text { Lower } \\
\text { Bound }\end{array}$ & $\begin{array}{l}\text { Upper } \\
\text { Bound }\end{array}$ & & \\
\hline \multirow[t]{3}{*}{ FA1 } & boys & 192 & 4,4260 &, 42334 & ,03055 & 4,3658 & 4,4863 & 3,20 & 5,00 \\
\hline & female & 250 & 4,4744 & ,39605 & ,02505 & 4,4251 & 4,5237 & 2,40 & 5,00 \\
\hline & Total & 442 & 4,4534 & ,40836 & ,01942 & 4,4152 & 4,4916 & 2,40 & 5,00 \\
\hline \multirow[t]{3}{*}{ FA2 } & boys & 193 & 2,9767 & 67804 & 04881 & 2,8804 & 3,0729 & 1,00 & 5,00 \\
\hline & female & 251 & 3,0169 & 61965 & ,03911 & 2,9399 & 3,0940 & 1,50 & 4,75 \\
\hline & Total & 444 & 2,9994 & ,64524 & ,03062 & 2,9393 & 3,0596 & 1,00 & 5,00 \\
\hline \multirow[t]{3}{*}{ FA3 } & boys & 191 & 3,7906 & 68595 & ,04963 & 3,6927 & 3,8885 & 1,67 & 5,00 \\
\hline & female & 251 & 3,7782 & ,61315 & ,03870 & 3,7020 & 3,8544 & 2,00 & 5,00 \\
\hline & Total & 442 & 3,7836 & 64489 & ,03067 & 3,7233 & 3,8438 & 1,67 & 5,00 \\
\hline \multirow[t]{3}{*}{ FA4 } & boys & 193 & 3,7133 & ,70433 & ,05070 & 3,6133 & 3,8133 & 1,00 & 5,00 \\
\hline & female & 251 & 3,8406 & 61486 & ,03881 & 3,7642 & 3,9171 & 2,33 & 5,00 \\
\hline & Total & 444 & 3,7853 & 65753 & ,03121 & 3,7240 & 3,8466 & 1,00 & 5,00 \\
\hline
\end{tabular}

Table 6. ANOVA table

\begin{tabular}{|c|c|c|c|c|c|c|}
\hline & & $\begin{array}{l}\text { Sum of } \\
\text { Squares }\end{array}$ & df & $\begin{array}{c}\text { Mean } \\
\text { Square }\end{array}$ & $\mathrm{F}$ & Sig. \\
\hline \multirow[t]{4}{*}{ FA1 } & $\begin{array}{l}\text { Between } \\
\text { Groups }\end{array}$ & 254 & 1 &, 254 & 1,525 & ,218 \\
\hline & Within & 73,286 & 440 & ,167 & & \\
\hline & Groups & & & & & \\
\hline & Total & 73,540 & 441 & & & \\
\hline \multirow[t]{4}{*}{ FA2 } & $\begin{array}{l}\text { Between } \\
\text { Groups }\end{array}$ & 177 & 1 & , 177 & 424 & ,515 \\
\hline & Within & 184,261 & 442 & ,417 & & \\
\hline & Groups & & & & & \\
\hline & Total & 184,437 & 443 & & & \\
\hline \multirow[t]{4}{*}{ FA3 } & $\begin{array}{l}\text { Between } \\
\text { Groups }\end{array}$ & , 017, & 1 & , 017, & ,040 & 842 \\
\hline & Within & 183,388 & 440 & 417 & & \\
\hline & Groups & & & & & \\
\hline & Total & 183,405 & 441 & & & \\
\hline \multirow[t]{4}{*}{ FA4 } & Between & 1,769 & 1 & 1,769 & 4,121 & ,043 \\
\hline & Groups & & & & & \\
\hline & $\begin{array}{l}\text { Within } \\
\text { Groups }\end{array}$ & 189,761 & 442 & ,429 & & \\
\hline & Total & 191,531 & 443 & & & \\
\hline
\end{tabular}


No significant difference between boys and females on (NEP) environmental concern found others studies (Arcury and Christianson, 1993; Widegren, 1988). No clear gender differences in environmental attitudes and behaviors support Hines et al., (1986-87). Although the majority of studies from 1988 to 1998 found that women reported significantly more general environmental concern than men, the effect of gender on NEP environmental attitudes was small (Zelezny et al, 2000: 444). In both adults and youth, the effect of gender (female) was stronger on proenvironmental behaviors than NEP environmental concerns (Zelezny et al, 2000). Their findings strongly suggest that environmentalism does not begin in adulthood, thus debunking the argument that gender differences in environmentalism arise with motherhood and protecting children from environmental threats (Hamilton, 1985; Levine, 1982; cited by Zelezny et al, 2000: 449). Mohai (1992) stated that "no firm conclusions can be drawn about the effects of gender on concern about general environmental issues, and more analysis and explanation clearly needs to be done in this area" (Mohai (1992: 2).

Females and boys in a sample of Macedonian students significantly differ in 4 out of 15 items, in 1 out of 4 factors, and on pro-DSP statements. Differences between the groups are probably resulting of their different level of knowledge about the environmental segments included into these items. In that direction, NEP scale was criticized for measuring cognitive beliefs based on learned facts rather than affective experience, based on emotional bond with nature (Mayer and Franz, 2004). We must not omit "the wealth of formative influences or significant life experiences that individuals bring to their further learning. Research has demonstrated that these may indeed be more significant than planned formal educational programs in the development of environmental understanding and concern" (Palmer, 2003).

Many factors create gender differences in environmental attitudes. The influences are grouped into 18 personal and social factors. A personality, for example, is more prominent among women (Luchs \& Mooradian, 2012). Compared to boys, females have higher levels of socialization to be other oriented and socially responsible (Zelezny et al., 2000). According many researches (Blocker \& Eckberg, 1997; Dietz et al., 2002; Stern et al., 1993; Zelezny et al. 2000), gender differences arising from traditional gender socialization. The reasoning is that females are more likely to be socialized to be communal and other-centered (which is more consistent with values of self-transcendence related to environmentalism), while boys are socialized to be agentic and competitive- which is more consistent with selfenhancement values contrary to environmentalism- (Burn et al. 2012). Women express more concern, but men are more knowledgeable (Arcury and Christianson, 1993; Gambro and Switzky, 1999; Gifford et al., 1982-83; Levine \& Strube, 2012; Arcury, Scollay and Johnson, 1987; Grieve VanStaden, 1985; Schahn and Holzer, 1990; Stern et al., 1993). Another explanation is that "altruistic concerns such as health and safety (which can be threatened by a degraded environment) are more important to women, especially to women with children at home" (Davidson and Freudenburg, 1996; Dietz et al., 2002). Environmental worldview may also differ based on culture. For example, due to cultural differences in traditional socialization, we might expect greater gender differences where traditional gender roles are the norm and smaller ones where gender roles are more equal (Burn et al., 2012).

Of course, there may be other explanations for gender differences in environmental attitudes. The relationship between gender and environmental concern has also tended to isolate gender without considering that the influence of gender may depend on other "intersectional" variables such as ethnicity, class, nationality, and region. In the case of gender and environmental concern, most of the research was conducted over a decade ago and the intersection of gender and culture is unexplored" (Burn et al. 2012). 
Empirical findings suggest that no firm and clear conclusions can be drawn about the effects of gender on (NEP) environmental concern in a sample of Macedonian students. In general, these findings suggest that genders do not differ on the NEP scale. A large majority of both female and boys students agree on all pro-environment statements. These findings support Davidson and Freudenberg's (1996) claim that gender differences in environmentalism are not universal (Davidson and Freudenberg, 1996). We cannot say whether existing differences are due to gender socialization and gendered roles but we can say that more research are needed on gender and the environment in environmental psychology and environmental sociology. From that, future studies should focus on all factors that create gender differences in environmental worldview. The number of these influences suggests that understanding pro-environmental concern is far more complex than previously thought (Gifford and Nilsson, 2014).

In general, across-gender differences do not exist between two groups. Few gender differences in environmental orientations are limited on some items or factors. From that, results do not support hypothesis. Our findings also suggest that equal attention should be paid to the role of both genders in the promotion of sustainability, although according to some studies, women tend to score higher on the environmental values that underlie environmental action.

It is important to note the limitations of this investigation. First, the random sample is relatively small. Second, the sample consisted only of students from elementary and secondary schools. Future researchers will use large, representative "mixed" samples to explain gender differences. In that direction, studying the cultural and contextual factors may explain gender differences, and provide information useful for the effective design of actions aimed at increasing environmental responsibility in a society.

Despite these limitations, these results provide an intriguing insight into gender differences in student's worldviews. Anyway, the present study is only a small part of ongoing studies of environmental worldview of the people in developing countries. In further research it would be interesting to explore other age groups, cultures and contexts with different educational activities and background.

\section{References}

- Arcury, T. A. \& Christianson, E. H. (1993). Rural-urban differences in environmental knowledge and actions. Journal of Environmental Education. 25, 19-25. DOI: 10.1080/00958964.1993.9941940.

- Arcury, T. A., Scollay, S. J. \& Johnson, T. P. (1987). Sex differences in environmental concern and knowledge: The case of acid rain. Sex Roles. 16 (9), 463-472. DOI: 10.1007/BF00292481.

- Banu, D. (1986). Secondary School Students' Attitudes towards Science. Research in Science and Technological Education. 4 (2), 195-202.

- Blocker, T. J. \& Eckberg, D. L. (1997). Gender and environmentalism: Results from the 1993 General Social Survey. Social Science Quarterly. 78 (4), 841-858. P.:17. URL: http://www.jstor.org/stable/42863735.

- Burn, M. Sh., Winter, L. P., Hori, B. \& Silver, N. C. (2012). Gender, Ethnic Identity, and Environmental Concern in Asian Americans and European Americans. Human Ecology Review. 19, 2. Retrieved August 3, 2016. from www: http://www.fs.fed.us/psw/publications/ winter/ psw_2012_winter001_burn.pdf.

- Castro, P. (2006). Applying social psychology to the study of environmental concern and environmental worldviews: Contributions from the social representations approach. Journal of Community \& Applied Social Psychology. 16, 247-266. DOI: 10.1 002/ casp. 864. 
- Davidson, D. J. \& Freudenburg, W. R. (1996). Gender and environmental risk concerns: A review and analysis of available research. Environment and Behavior. 28, (3), 302-339. DOI: 10.1177/0013916596283003.

- Davidson, D. \& Freudenberg W. (1996). Gender and Environmental Risk Concerns. A Review and Analysis of Available Research. Environment and Behavior. 28 (3), 302-339. DOI: 10.1177/0013916596283003.

- Dietz, T., Kalof, L. \& Stern, P. C. (2002). Gender, values, and environmentalism. Social Science Quarterly. 83, 353-364. DOI: 10.1111/1540-6237.00088.

- Dunlap, R. E. \& Van Liere, K. D. (1978). The New Environmental Paradigm: A Proposed Measuring Instrument and Preliminary Results. The Journal of Environmental Education. 9 (4), 10-19. DOI: 10.1080/00958964.1978.10801875.

- Dunlap, R. E., Van Liere, K. D., Mertig, A. G. \& Jones, R. E. (2000). Measuring the endorsement of the New Ecological Paradigm: a revised NEP scale. Journal of Social Issues. 56 (3), 425-442. Retrieved August 3, 2016. from www: http://academic.evergreen. edu/s/smitht/NEP.pdf.

- European Commission (2016). Sustainable Development. Retrieved August 2, 2016. from www: http:// ec.europa.eu/environment/eussd/2.8.2016.

- Gambro, J. S. \& Switzky, H. N. (1999). Variables associated with American high school students' knowledge of environmental issues relates to energy and pollution. Journal of Environmental Education. 30 (2), 15-22. DOI: $10.1080 / 00958969909601866$.

- Gifford, R., Hay, R. \& Boros, K. (1982/83). Individual differences in environmental attitudes. Journal of Environmental Education. 14 (2), 19-23. DOI: 10.10.80/00958964.1983.10801933.

- Gifford, R. \& Nilsson, A. (2014). Personal and social factors that influence pro-environmental concern and behaviour: A review. International Journal of Psychology. 49 (3), 141-157. DOI: 10.1002/ijop.12034.

- Gillaspy, R. (2015). Environmental Worldviews: Western \& Deep Ecology. Retrieved August 2, 2016. from www: http://study.com/academy/lesson/environmental-worldviews-western-deep-ecology. html\#transcriptHeader.

- Grieve, K. W. \& Van Staden, F. J. (1985). Environmental concern in South Africa: An attitudinal study. South African Journal of Psychology. 15, 135-13. DOI: 10.1177/008124638501500405.

- Gutteling, J. M. \& Wiegman, O. (1993). Gender-specific reactions to environmental hazards in the Netherlands. Sex Roles. 28, 433-447. DOI: 10.1007/BF00289606.

- Hines, J., Hungerford, H. \& Tomera, A. (1986/87). Analysis and synthesis of research on responsible environmental behavior. Journal of Environmental Education. 18, 1-8. DOI: 10.10.80/00958964.1987.9943482.

- Hunter, L., Hatch A. \& Johnson A. (2004). Cross-National Gender Variation in Environmental Behaviors. Social Science Quarterly. 85 (3), 677. DOI: 10.1111/j.0038-4941.2004.00239.

- Idrizi, A., Srbinovski, M. \& Jonuzi, I. (2014). Attitudes of Macedonian High School Students towards the Environment. Procedia- Social and Behavioral Sciences. 159, 636 - 642. DOI: 10.1016/j.sbspro.2014.12.439.

- Ismaili, M., Abazi, A. \& Srbinovski, M. (2009). Students level of environmental education in Macedonian high schools. SEEU (South-East European University) Review. 5 (2), 125-135. Retrieved August 1, 2016. from www: http://www.seeu.edu.mk/files/seeu_review_5.2.pdf.

- Jelle Boeve-de Pauwl, Karen J. \& Van Petegem P. (2014). Environment and Behavior. 46 (3), 373-397. Retrieved August 2, 2016 from www: http://eab.sagepub.com/content/ 46/3/373.abstract. 
- Joachim Schahn (1990). Studies of Individual Environmental Concern. The Role of Knowledge, Gender, and Background Variables, Environment and Behavior. 22 (6), 767-786. Retrieved August 2, 2016. from www: http://eab.sagepub.com/content/22/6/767.abstract.

- Levine, D. S. \& Strube, M. J. (2012). Environmental attitudes, knowledge, intentions and behaviors among college students. Journal of Social Psychology. 152, 308-326. DOI: 10.1080/00224545.2011.604363.

- Luchs, M. \& Mooradian, T. (2012). Sex, personality, and sustainable consumer behaviour: Elucidating the gender effect. Journal of Consumer Policy. 35, 127-144. DOI: 10.1007/s10603-011-9179-0.

- Maloney, M. P., Ward, M. P. \& Braucht, G. N. (1975). A revised scale for the measurement of ecological attitudes and knowledge. American psychologist. 30 (7), 787-790. DOI: 10.1037/h0084394.

- Mayer, S. F. \& McPherson Franz, C. (2004). The connectedness to nature scale: A measure of individuals' feeling in community with nature. Journal of Environmental Psychology. 24, 503-515.

- Milfont, T. L., Duckitt. J. \& Cameron, L. D. (2006). A cross-cultural study of environmental motive concerns and their implications for proenvironmental behavior. Environment and Behavior. 1 (38), 745-767. DOI: 10.1177/0013916505285933.

- Mohai, P. (1992). Men, women, and the environment: An Examination of the Gender Gap in Environmental Concern and Activism. Society and Natural Resources. 5, 1-19. DOI: 10.1080/08941929209380772.

- OSCE (2009). Gender and Environment. A guide to the Integration of gender aspects in the OSCE's environmental projects, 17. Retrieved August 13, 2016. from www: http://www.osce.org/gender/36360.

- Palmer, J. A. (2003). Environmental education in the 21 st century, theory, practice, progress and promise. London and New York: Routledge.

- Stern, P. C., Dietz, T. \& Kalof, L. (1993). Value Orientations, Gender, and Environmental Concern. Environment and Behavior. 25, 322-348. DOI: 10.1177/0013916593255002.

- Rideout, B. E., Hushen, K., McGinty, D., Perkins, S. \& Tate, J. (2005). Endorsement of the New Ecological Paradigm in systematic and e-mail samples of college students. Journal of Environmental Education. 36 (2), 15-23. DOI: 10.3200/JOEE.36.2.15-23.

- Scannell, L. \& Gifford, R. (2013). The role of place attachment in receptivity to local and global climate change message framing in engagement. Environment and Behavior. 45 (1), 60-85. DOI: 10.1177/0013916511421196.

- Schahn, J. \& Holzer, E. (1990). Studies of individual environmental concern: The role of knowledge, gender, and background variables. Environment and Behavior. 22, 767-786. DOI: 10.1177/0013916590226003.

- Schultz, P. W. (2001). The structure of environmental concern: Concern for self, other people, and the biosphere. Journal of Environmental Psychology. 21, 327-339. DOI: 10.1006/jevp.2001.0227.

- Schultz, P. \& Zelezny, L. (2003). Reframing environmental messages to be congruent with American values. Research in Human Ecology. 10 (2), 126-136. Retrieved August 3, 2016. from www: http:// ww.humanecologyreview.org/pastissues/her102/102scultzzelezny.pdf.

- Raschka, S. (2015). Principal Component Analysis in 3 Simple Steps. Retrieved October 20, 2016. from www: http://sebastianraschka.com/Articles/2015_pca_in_3_steps.html.

- Srbinovski, M. (2001). Environmental education in primary and secondary schools in the Republic of Macedonia: a biological point of view (doctoral dissertation). Skopje: Faculty of Natural Sciences and Mathematics. 
- Srbinovski, M. (2004). Some aspects of the students' environmental education in the Republic of Macedonia. Natura Montenegrina. 3, 257-268. UDK: 364.2:37.016:502/ 504(497.7)(045)=111.

- Srbinovski, M. (2005a). Environmental Education. Skopje: Prosvetno delo.

- Srbinovski, M. (2005b). The relationships between some cognitive and affective environmental educational areas. SEEU (South-East European University) Review 2 (2), 223-239. ISSN: 1409-7001.

- Srbinovski, M. (2006). Students' effective attitudes towards the environment, Teaching and education, 1: 2233, ISSN: 0547-3330: eISSN: 2560-3051

- Stern, P. C., Dietz, T. \& Kalof, L. (1993). Value orientations, gender, and environmental concern. Environment and Behavior. 25 (5), 322-348, DOI: 10.1177/0013916593255002.

- Stokols, D. (1995). The paradox of environmental psychology. American Psychologist. 50 (10), 821-837. DOI: 10.1037/0003-066X.50.10.821.

- Tikka, P. M., Kuitnen, M. T. \& Tynys, S. M. (2000). Effects of educational background on students' attitudes, activity levels, and knowledge concerning the environment. Journal of Environmental Education. 31 (3), 12 19. DOI: $10.1080 / 00958960009598640$.

- Tuncer, G., Ertepinar, H., Tekkaya, C. \& Sungur, S. (2005). Environmental Attitudes of Young People in Turkey: Effects of School Type and Gender. Environmental Education Research. 11 (2), 215-233. DOI: $10.1080 / 1350462042000338379$.

- UALR College of Business (2016). One-Way Analysis of Variance (ANOVA) Example Problem. Retrieved August 2, 2016. from www: http://cba.ualr.edu/smartstat/topics/anova/example.pdf.

- Van Liere, K. D. \& Dunlap, R. E. (1980). The social bases of environmental concern: A review of hypotheses, explanations, and empirical evidence. Public Opinion Quarterly. 44 (2), 181-197. DOI: 10.1086/268583.

- Weigel, R. \& Weigel, J. (1978). Environmental concern: the development of a measure. Environment and Behavior. 10 (1), 3-15. DOI: 10.1177/0013916578101001.

- Wiidegren, O. (1988). The new environmental paradigm and personal norms. Environment and Behavior. 30 (1), 75-100. DOI: 10.1177/0013916598301004.

- Wiseman, M. \& Bogner, F. X. (2003). A higher-order model of ecological values and its relationship to personality. Personality and Individual Differences. 34 (5), 783-794. DOI: 10.1016/S0191-8869(02)00071-5.

- Woodford, C. (2016). Environmentalism. Retrieved August 3, 2016 from www: http://www.explainthatstuff. com/introduction-to-environmentalism.html.

- World Commission on Environment and Development (2016). Our Common Future. Retrieved August 3, 2016. from www: http://www.un-documents.net/our-common-future.pdf.

- Xiao, C. \& Hong, D. (2010). Gender differences in environmental behaviors in China. Population and Environment. 32 (1), 88-104. DOI: 10.1007/s11111-010-0115-z.

- Zelezny, L. C., Chua, P. P. \& Aldrich, C. (2000). New Ways of Thinking about Environmentalism: Elaborating on gender differences in environmentalism. Journal of Social Issues. 56 (3), 443-457, DOI: 10.1111/00224537.00177 . 
Gender Differences in Environmentalism: A Case Study of Macedonian Students

\section{Миле С. Србиновски}

Универзитет југоисточне Европе, Институт за животну средину и здравље

Тетово, Македонија

\section{Родне разлике и еколошки поглед на свет: студија случаја из Македоније}

Резиме: У овој сииуяији бавимо се уйииајем йола на еколошки йоїлеg на свети и забри-

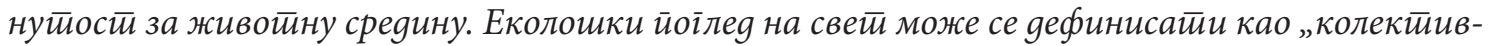
на увереюа и вредностии који љьудим gају ирреgстиву о йоме како свет функиионише, која је нихова улої у животиној средини, као и које йонашатье је исиравно или йоірешно у ояносу на животину среgину" (Gillaspy, 2015: 1). Забринуйосии за живойну среgину gефинише се као

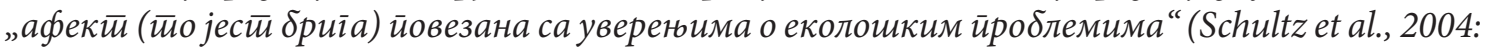
31). „Научници из областии gрушитвених наука имају мотиив gа се баве еколошком забринуйошћу затио шито, ако желимо gа ияемо у ирравиу одрживостии животине среgине, морамо

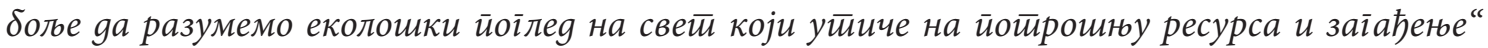
(Castro, 2006: 248), као важан gео „околностии у којима йојеgинии и ірруйе gоносе оллуке и

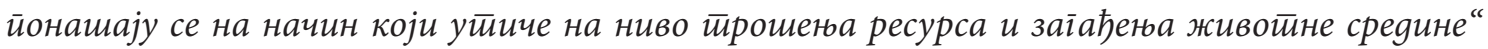
(Stokols, 1995: 828).

Изнетиа је слеgећа хийоиеза: Буgући gа су мноїа истираживаға у којима су мушкарии и жене йоређени коришћеюем ревияиране скале Нове еколошке йараgиіме (НЕП) йоказала gа жене имају већи број иоена о мушкараца, ми очекујемо истии ииакав резулитаи. Користиили смо ревияирану скалу Нове еколошке йараgиіме, йознаиичју као НЕП скала, коју су консиируисали Данлай и сараgниии (Dunlap et al., 2000). У овој скали оg иееитнаести стиавки користии

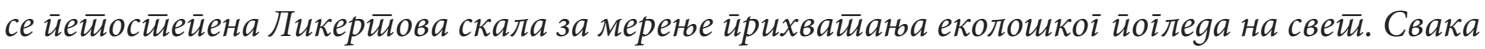
сииавка мерена је на скали оg 1 gо 5: йоййуно се слажем (5), слажем се (4), неоллучан сам (3), не слажем се (2) и уойшие се не стажем (1). Слаїане са осам сииавки йоg нейарним бројевима указује на йро-НЕП оријенйаиију, док слаїаюе са сеgам сииавки йоg йарним бројевима указује на ирро-ДСП оријенииацију (доминанитна соиијална йараgиіма). Поузданости НЕП скале

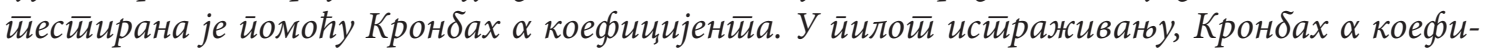

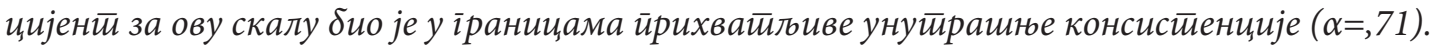

Узорак коришћен у финалној анализи чинило је четиристио четирgесети осам ученика макеgонских основних и среgюих школа (стио gевеgесети тири gечака или 43, $1 \%$ и gвестй йеgесей gве gевојчице или 56,3\%). Школе су оgабране на основу достиуйностии и жеље gа сарађују у истираживану.

Извриили смо факт̄орску анализу ілтвних комӣоненӣи (Principal Components Analysis, РСА) са варимакс ротиацијом како бисмо уйвряили ирисустиво или одсустиво димензија. $3 а$

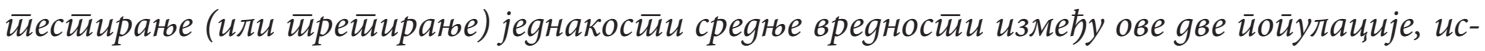

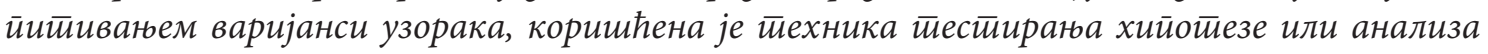
варијансе (Analysis of Variance, ANOVA).

Укуйна среgна вреgности йро-НЕП\% девојчица и дечака скоро је ияенииччна (56,63\% и 56,80\%). Хи-кваgрати йестиови (Chi-square test) нису били ирримениви на јеgанаести стиавки

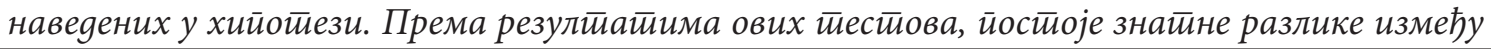


gевојчица и дечака у четиири ов иетинаести стиавки. Уочена је значајна разлика у сииавовима у gве изјаве на .05 нивоу и.01 нивоу.

По йитиағьу йро-НЕП изјава, не йосйоји разлика између стиавова дечака и gевојчииза ( $\left.\chi^{2}=0.267\right)$. Иако су среgне вредносиии ирро-ДСП\% іотиово ияенииччне $(48,02 \%$ gевојчице и 47,96\% gечаци), уочена је велика разлика у сииавовима који се оgносе на ове изјаве између

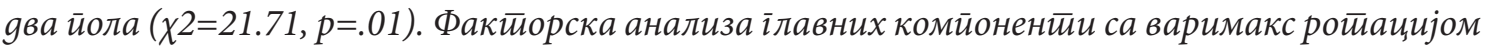

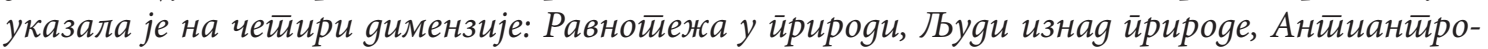

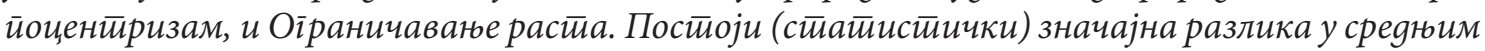
вредносииима између gве ірруие исиийаника (среgюа вредности за женски йол = 3.84, SD=0.61;

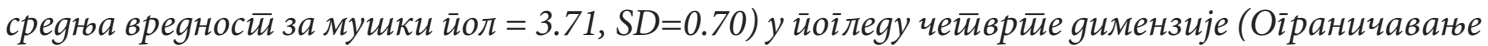

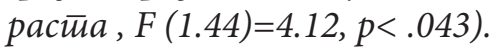

Емитиријски резулитайи истираживана сировеgеноі на узорку макеgонских ученика указују на чиюенииу gа се не моі̄у извући чврстич и јасни закључци о уйицају йола на (НЕП)

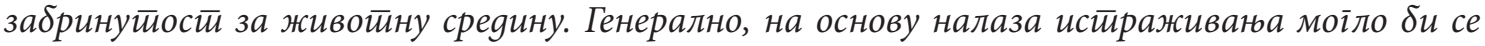
заклучити да на НЕП скали нема разлике између йолова. Већина ученика и ученица има истие сииавове каgа је реч о ирроеколошким изјавама. Ови налази йойврђују мишљене Дејвиясона и Фројgенберіа (Davidson \& Freudenberg, 1996) gа роgне разлике нису универзалне у еколошком йоілеgу на свети. Маgа не можемо са сиіурноићу йврgитии gа су родна социјатизација и рояне улоїе узрок йостиојећих разлика, извесно је да еколошка йсихолоїија и еко-

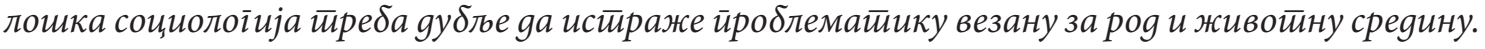
У неким буgућим научним стиуяијама тиреба се фокусиратии на све фактиоре који довоgе gо

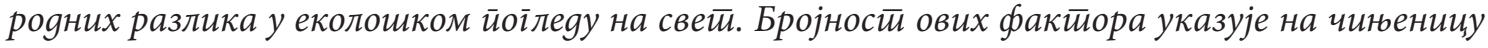

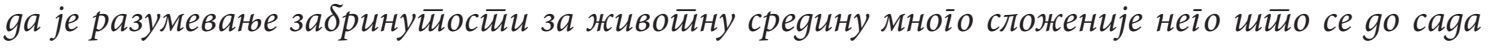
мислило (Gifford \& Nilsson, 2014: 114).

Уойшиенно іоворећи, не йостиоје рояне разлике између gве ірруие тесесиираних ученика. Неколико родних разлика у йоілеgу еколошке оријентиаиие уочено је само кол неких стиавки и јеgноі фактиора (димензије). Резулитайи истираживаға не йодржавају изнетиу хийойезу. Они тиакође указују на йойребу gа се йосебна йажна йосветии улози оба йола у иромовисаньу

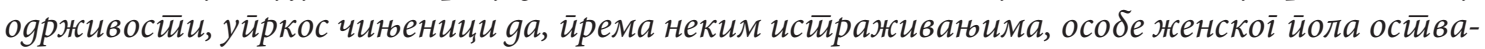
рују боли резулитай каяа је реч о еколошким вреgностима на којима се заснива еколошко gеловане.

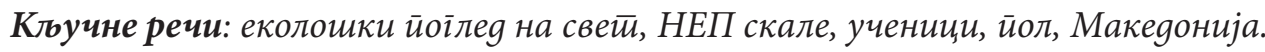

